\title{
TESTS OF CAUSTIC MAGNESIA MADE FROM MAG- NESITE FROM SEVERAL SOURCES.
}

\author{
By P. H. Bates, Roy N. Young, and Paul Rapp.
}

ABSTRACT.

The properties of oxychloride cement have been studied, particularly in relation to the source (or properties) of the magnesite ore, conditions during calcination of the ore, and various oxychloride cement mixtures. Ore from Greece, from two different sources in California, and from the State of Washington were used. The first three are of the amorphous variety; the last is coarsely crystalline. Each ore was crushed and separated into three lots, differing only in size of particles. Each lot was then calcined under fixed conditions throughout the operation. The temperature range, including all burns, was from 700 to $\mathrm{I}, 100^{\circ} \mathrm{C}$. Each lot of calcined ore was prepared for use by grinding-in some cases "aging" was necessary-and used in three flooring formulas, two stucco formulas, and one laboratory test formula. Only one concentration $\left(22^{\circ} \mathrm{B}\right.$.) of magnesium chloride solution was mixed with the dry materials and the consistencies of the wet mixtures (excepting the laboratory test mix) were kept as nearly the same as possible.

Service tests were made in conjunction with the laboratory tests. The service tests consisted of the laying of flooring panels; erection of stucco panels, all exposed to actual service conditions; and subsequent observations. The chief laboratory tests were: (I) Time of set, (2) strength tests (tensile, transverse, and compressive), (3) water resistance, and (4) change in volume. The results show that the various ores used require different conditions of calcination in order to produce caustic magnesias of approximately the same quality. The behavior of the cement mixture is affected to a very great extent by variations in: (I) The degree of calcination of the ore, (2) the various types of aggregates often used in practice, and (3) the relative amounts of given constituents in a mixture.

\section{CONTENTS.}

Page.

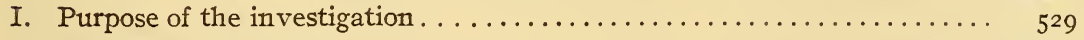

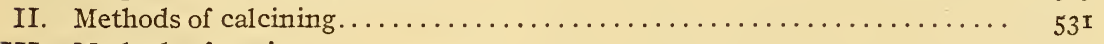

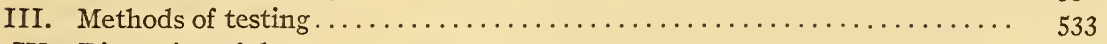

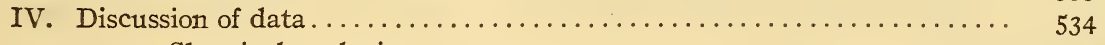

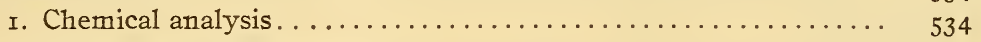

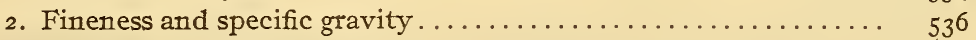

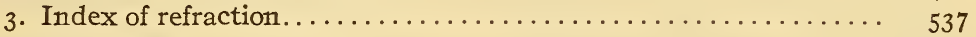

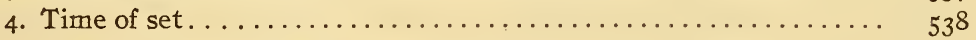

5. Strength of specimens. . . . . .

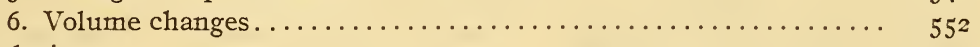

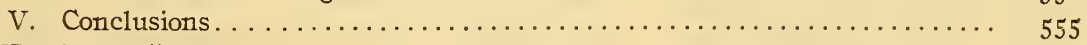

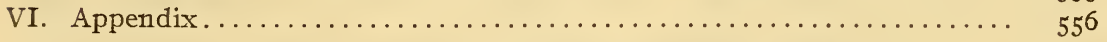

\section{PURPOSE OF THE INVESTIGATION.}

In view of the fact that the physical properties of caustic magnesia produced by burning magnesite at relatively low temperatures (under $\mathrm{I}, \mathrm{IOO}^{\circ} \mathrm{C}$.) have been found to vary considerably, the 
Oxychloride Cement Association suggested to the bureau the desirability of conducting an investigation in which these variations should be studied. As it has also been stated that magnesites from different deposits require different burning temperatures to produce magnesia of the same quality, it was deemed advisable to include this factor also in the study.

At the time the investigation was started practically all the caustic magnesia used in this country was being produced from deposits in California. One of those most actively worked was located at Livermore, and the other, consisting of two mines, was located close to Porterville. There are a number of other large deposits in this State, but at that time they were being operated but intermittently, or other difficulties intervened so that ore for the purpose of this investigation could be obtained only from the Livermore and Porterville mines. These ores, however, seemed to be typical of the so-called amorphous magnesites, and were thought to represent what extremes might be encountered in such closely similarly appearing material.

At the same time the large deposits of crystalline magnesite, located near Vallery and Chewelah, Stevens County, Wash., were being extensively worked as a source of "dead burned" magnesia for use in making refractories. This type of magnesite had been imported into this country before the late war in large quantities from Austria-Hungary to supply the refractory trade. However, none had been used for producing caustic magnesia in this country, though it was reported then and it has since been confirmed that it was being burned for this purpose abroad. As the deposits in Washington are very extensive, comparatively close to the railroad, and of a purity that would permit its use for caustic burning, a shipment for experimental burning was obtained from Chewelah.

The importation of magnesia at the time the investigation was started had been practically cut off, due to the war conditions. However, a small lot of amorphous ore from Greece was located and a shipment obtained. From what locality in Greece it originated is not known, but it was stated by those acquainted with the ore from that country to be representative. It should be stated that before the war the greater part of the caustic magnesia used in this country came from Greece. Some was imported as ore and calcined here, but by far the greater part arrived as caustic, having been burned for the carbonic acid gas, generally in Holland. 
There were, therefore, obtained and used in this investigation, two 2-ton shipments of the ore representative of that being used in this country, the ore from Livermore and Porterville (referred to hereafter as $\mathrm{D}$ and $\mathrm{C}$, respectively), a shipment of about the same amount of crystalline ore from Washington (sample A), which deposit offers a very large source of readily worked and accessible ore, and a 2-ton shipment of Grecian (sample B) ore, which ore had been the source of practically all the caustic used in this country before I 915 .

\section{METHODS OF CALCINING.}

Two factors other than the source which were also considered in burning the magnesite were the size as fed to the kiln and the temperature of burning. In making the calcinations, a rotary kiln 30 feet long and 18 inches inside diameter was used with a constant speed of one revolution per minute. It was not possible, consequently, to consider the effect of time of burning, although this phase of burning did enter into the question in a somewhat uncontrollable manner in that with the same speed of revolution the different sized ore would pass through the kiln in different times, which varied from I hour and ro minutes to I hour and 45 minutes. Originally it was intended to burn each of the three sizes at 700,800 , and $900^{\circ} \mathrm{C}$., and one higher temperature to be determined after the results of the first burns were available. However, it was soon noted that the large size would be decidedly underburned at the lower temperatures. It was also thought that the small size would be overburned at the higher temperatures, although later results do not confirm this. Hence the procedure provisionally adopted was the burning of the crushed ore sized to pass a I-inch screen but retained on the half inch, at $900^{\circ} \mathrm{C}$., that passing the half inch but retained on the quarter, at $800^{\circ} \mathrm{C}$., and that passing the quarter but retained on the eighth inch, at $700^{\circ} \mathrm{C}$. The first burn made at $700^{\circ}$ showed the necessity of modifying the procedure, as very quick-setting oxides were being obtained. It was therefore decided to vary the temperature for each size of each kind of ore according to the results of some preliminary work. The temperatures used are given in Table I. These are the lowest temperatures at which any particular size of ore could be burned and give an oxide which would have a workable time of set after aging a reasonable length of time. 
TABLE 1.-Results of Certain Tests of the Finished Burned Materials.

\begin{tabular}{|c|c|c|c|c|c|c|c|c|c|}
\hline \multirow{2}{*}{ Magnesite. } & \multirow{2}{*}{$\begin{array}{l}\text { Size of } \\
\text { ore.1 }\end{array}$} & \multirow{2}{*}{$\begin{array}{l}\text { Tem- } \\
\text { pera- } \\
\text { ture of } \\
\text { burn. }\end{array}$} & \multicolumn{2}{|c|}{$\begin{array}{l}\text { Fineness through } \\
\text { sieve. }\end{array}$} & \multirow{2}{*}{$\begin{array}{l}\text { Specific } \\
\text { gravity. }\end{array}$} & \multicolumn{2}{|c|}{$\begin{array}{l}\text { Weight per cubic } \\
\text { foot. }\end{array}$} & \multirow{2}{*}{$\mathrm{CO}_{2}$} & \multirow{2}{*}{$\begin{array}{l}\text { Loss on } \\
\text { ignition. }\end{array}$} \\
\hline & & & No. 100 . & No. 200. & & Loose. & Packed. & & \\
\hline A.. & 2 and $\frac{1}{3}$ & $\begin{array}{l}{ }^{\circ} \mathrm{C} . \\
900 \\
800\end{array}$ & $\begin{array}{r}\text { Per cent. } \\
98.4 \\
99.1\end{array}$ & $\begin{array}{r}\text { Per cent. } \\
85.6 \\
89.5\end{array}$ & $\begin{array}{l}3.28 \\
3.22\end{array}$ & $\begin{array}{r}\text { Ibs. } \\
47.9 \\
44.9\end{array}$ & $\begin{array}{r}\text { Lbs. } \\
58.5 \\
55.3\end{array}$ & $\begin{array}{l}2.31 \\
3.34\end{array}$ & $\begin{array}{l}5.59 \\
5.98\end{array}$ \\
\hline B......... & $\begin{array}{l}1 \\
2 \\
3\end{array}$ & $\begin{array}{l}900 \\
800 \\
700\end{array}$ & $\begin{array}{l}84.4 \\
93.9 \\
95.4\end{array}$ & $\begin{array}{lll}2 & 52.2 \\
2 & 70.9 \\
2 & 73.7\end{array}$ & $\begin{array}{l}3.38 \\
3.31 \\
3.06\end{array}$ & $\begin{array}{l}44.4 \\
39.2 \\
46.5\end{array}$ & $\begin{array}{l}566 \\
49.1 \\
54.8\end{array}$ & $\begin{array}{r}0.68 \\
0.97 \\
14.44\end{array}$ & $\begin{array}{r}2.00 \\
3.08 \\
18.07\end{array}$ \\
\hline C....... & $\begin{array}{l}1 \\
1 \\
2 \\
3\end{array}$ & $\begin{array}{r}1,100 \\
900 \\
800 \\
750\end{array}$ & $\begin{array}{l}96.6 \\
92.4 \\
98.0 \\
97.6\end{array}$ & $\begin{array}{l}78.2 \\
73.2 \\
81.3 \\
88.7\end{array}$ & $\begin{array}{l}3.36 \\
3.27 \\
2.85 \\
2.62\end{array}$ & $\begin{array}{l}47.4 \\
43.0 \\
50.2 \\
50.8\end{array}$ & $\begin{array}{l}64.2 \\
51.5 \\
68.3 \\
60.2\end{array}$ & $\begin{array}{r}0.77 \\
1.88 \\
6.52 \\
13.97\end{array}$ & $\begin{array}{r}1.86 \\
5.13 \\
10.34 \\
25.80\end{array}$ \\
\hline D................. & $\begin{array}{l}1 \\
2 \\
3\end{array}$ & $\begin{array}{l}900 \\
850 \\
800\end{array}$ & $\begin{array}{l}86.5 \\
99.5 \\
98.5\end{array}$ & $\begin{array}{r}258.0 \\
82.0 \\
81.6\end{array}$ & $\begin{array}{l}3.42 \\
3.02 \\
3.02\end{array}$ & $\begin{array}{l}52.6 \\
44.2 \\
43.4\end{array}$ & $\begin{array}{l}64.2 \\
52.8 \\
56.2\end{array}$ & $\begin{array}{l}0.99 \\
4.40 \\
6.35\end{array}$ & $\begin{array}{r}3.01 \\
11.18 \\
12.93\end{array}$ \\
\hline
\end{tabular}

1 Size $x$, passing $x$-inch but retained on $1 / 2$-inch screen; size 2 , passing $1 / 2$-inch but retained on $1 / 4$-inch screen; and size 3 , passing $1 / 4$-inch but retained on No. 8 screen.

${ }^{2}$ Clogged screen. Particles agglomerated.

TABLE 2.-Composition of Dry Mixes.

Per ce:-t by Weight.

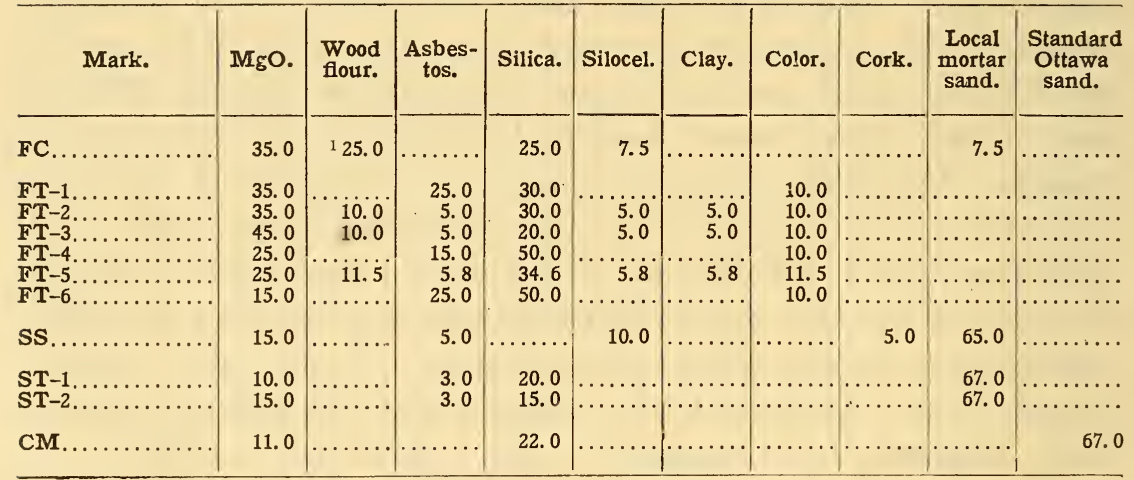

\footnotetext{
${ }^{1}$ Sawdust.
}

$\mathrm{FC}=$ flooring cushion. $\mathrm{SS}=$ stucco scratch. $\mathrm{CM}=$ standard mix. FT=flooring top coat. $\mathrm{ST}=$ stucco top coat.

Asbestos. Mixture of equal parts $\mathrm{C}$ and $\mathrm{D}$ grades.

Silica. Ground potters' flint, fineness 99.0 per cent passing 100 -mesh sieve and 89.6 per cent passing 200-mesh sieve.

Clay. Newark kaolin. Color. Red iron oxide.

Sieve Analyses for Aggregates: Per Cent Passing Indicated Sieves.

\begin{tabular}{|c|c|c|c|}
\hline $\begin{array}{l}\text { U. S. } \\
\text { standard } \\
\text { sieve No. }\end{array}$ & Cork. & $\begin{array}{l}\text { Local } \\
\text { sand. }\end{array}$ & $\begin{array}{l}\text { Wood } \\
\text { flour. }\end{array}$ \\
\hline $\begin{array}{l}8 \ldots \ldots \\
16 \ldots \\
30 \ldots \\
50 \ldots \\
100 \ldots \\
200 \ldots\end{array}$ & $\begin{array}{r}100.0 \\
98.7 \\
77.6 \\
44.3 \\
31.7 \\
25.5\end{array}$ & $\begin{array}{r}100.0 \\
99.4 \\
88.0 \\
33.4 \\
5.8 \\
2.2\end{array}$ & $\begin{array}{l}99.9 \\
99.8 \\
98.8 \\
90.6 \\
64.5 \\
35.6\end{array}$ \\
\hline
\end{tabular}




\section{METHODS OF TESTING.}

After calcination the magnesia was ground in a ball mill to the fineness indicated in Table $\mathrm{r}$. The agglomeration of the particles makes it practically impossible to obtain the true finess by dry sieving. Sieving by the use of water is prohibitive on account of the very rapid hydration of the lower burned oxides. The fineness indicated for the No. 200 sieve is, therefore, in certain cases, considerably lower than the true value.

The physical properties of the oxides so prepared, when used in the form of several flooring and stucco mixtures (see Table 2), were determined according to the tests indicated in Tables 5 and 7. In addition to these laboratory tests, duplicate test panels of all of these mixtures, excepting the CM mix, were placed in actual service. Each test panel covers from 25 to 35 square feet. In the case of the flooring mixtures, one panel was placed where it would be subjected generally to more wear than the other. They were placed over a finished concrete floor, to which expanded metal lath had been attached. The stucco mixes were placed upon the hollow-tile wall of a penthouse, one receiving an eastern or northern exposure and the duplicate a western or southern exposure.

The formulas used in these various test pieces are not suggested for general use. In practical work no fixed formula should ever be used. The variations in the quality of the oxides purchased or in the aggregates used are such as may require the modification of any formula. What is desired is a product having certain physical qualities and not one of a certain fixed composition. The latter could be used for test purposes to determine the physical qualities of the different ingredients in the mix, varying not more than one of these ingredients at a time. The limited number of formulas used were chosen especially as being typical of the general type in practical use. This is particularly true of the stucco formulas and flooring formula $\mathrm{F} T-3$, although in the former case, $\mathrm{ST}-\mathrm{I}$ and ST-2 may be considered as representing the minimum and the maximum percentages, respectively, of oxides which are generally used.

The flooring formula $\mathrm{F}^{\mathrm{T}} \mathrm{T}-3$, while it is typical of the number, amounts, and character of the various ingredients generally used in flooring mixes, contained an amount of magnesia which was until recently considered somewhat toward the lower limit used in practice. This constituent may be increased up to 60 per cent 
in practice at the expense of one or more of the other constituents. But in the case of active magnesias, such as those under investigation were, it is well to hold this constituent to a minimum amount, and therefore the effect of a still lower amount of oxide was studied by reducing by ro per cent the amount used in $\mathrm{FT}-3$, with an addition of an equivalent amount of silica and obtaining formula FT-2. FT-I was used in order to see if a laboratory test formula, in which was present but one of each of those types of aggregates generally used [fibrous (asbestos and wood flour), inert filler (silica), and color], could be used to determine both the useability of any magnesia and the serviceability of such a formula in actual use. F $\mathrm{T}-4, \mathrm{~F} T-5$, and $\mathrm{F} T-6$ were substituted in a few exceptional cases, when the use of either of the above formulas indicated the desirability of a change. This is the case of magnesia $\mathrm{A}$, the flooring panel of mix $\mathrm{F} T-\mathrm{I}$, which showed a tendency to "dish," crack, and separate from the ground coat, hence mix FT-4 was used. In this latter the silica was increased to 50 per cent by reducing both the magnesia and asbestos of FT-I Io per cent.

\section{DISCUSSION OF DATA.}

\section{CHEMICAL ANALYSIS.}

The results of the chemical analyses of the ores are shown in Table 3. While a 2-ton shipment might be considered sufficiently large to afford a representative sample, yet it can only be such in a limited sense. Having been taken from the output of a crusher or from a stock bin, it is only representative of the crusher output or of the material in the bin at that time and not of the whole deposit. However, judging from the analyses of the magnesites, the imported contains more magnesium carbonate than the domestic. This difference is but small in amount and other samples from the same domestic sources as these which supplied samples have been equally pure, with the possible exception of the domestic crystalline magnesite. An examination of the data from the physical tests will reveal that the quality of a calcined magnesite is not so much a matter of actual content of magnesia as it is a matter of burning or aging after burning. While if the two latter requirements of preparation are properly met, the magnesite of higher magnesia content would quite likely produce the better caustic, these two requisites are more likely to vary and are more difficult to control than the composition of the ore delivered to the kiln. 
TABLE 3.-Results of Chemical Analyses of the Ores.

\begin{tabular}{|c|c|c|c|c|c|c|c|c|c|}
\hline $\begin{array}{l}\text { Mag- } \\
\text { nesite. }\end{array}$ & $\mathrm{SiO}_{2}$ & $\mathrm{Fe}_{2} \mathrm{O}_{3}$ & $\mathrm{Al}_{2} \mathrm{O}_{3}$ & $\mathrm{CaO}$ & $\mathrm{MgO}$. & MnO. & $\mathrm{CO}_{2 .}$ & $\begin{array}{l}\text { Ignition } \\
\text { loss. }\end{array}$ & $\begin{array}{l}\text { Insoluble } \\
\text { residue. }\end{array}$ \\
\hline & $\begin{array}{l}5.59 \\
1.54\end{array}$ & $\begin{array}{r}0.79 \\
.26 \\
44\end{array}$ & $\begin{array}{r}1.69 \\
.76 \\
26\end{array}$ & $\begin{array}{l}1.48 \\
1.06 \\
1.13\end{array}$ & $\begin{array}{l}42.25 \\
46.07 \\
46.00\end{array}$ & $\begin{array}{l}0.13 \\
\text { Ni1. } \\
\text { Niv. }\end{array}$ & $\begin{array}{l}36.48 \\
50.31 \\
48.85\end{array}$ & $\begin{array}{l}48.23 \\
50.61 \\
49.46\end{array}$ & $\begin{array}{r}7.80 \\
3.29 \\
3.47\end{array}$ \\
\hline D... & $\begin{array}{l}\text { 1.12 } \\
1.72\end{array}$ & .28 & .24 & $\begin{array}{l}1.13 \\
2.82\end{array}$ & 44.74 & $\begin{array}{l}\text { Ni1. } \\
\text { Nil. }\end{array}$ & $\begin{array}{l}48.85 \\
50.70\end{array}$ & $\begin{array}{l}49.40 \\
50.70\end{array}$ & $\begin{array}{r}.47 \\
.44\end{array}$ \\
\hline
\end{tabular}

The high values for the ignition loss and carbonic acid (see Table I) in certain of the low-burned materials is due to underburning in some cases and aging in others. All magnesia after burning and without grinding was stored for two months in large cans with loosely fitting covers in the kiln house. It was then ground and used in the case of the two first oxides listed in the table. The last two listed burned at $850^{\circ}$ or lower were aged in bags in the laboratory from one to four months after grinding. This was necessary in order to retard the time of set sufficiently to make the ground oxide usable. The oxide from magnesite $\mathrm{B}$ burned at $700^{\circ} \mathrm{C}$. (not aged after grinding) had an ignition loss of I8. I per cent and was so quick setting as to be unusable. The oxide from magnesite $\mathrm{C}$ burned at $750^{\circ} \mathrm{C}$. had, before aging, an ignition loss of 15.0 per cent, and after aging two months after grinding, a loss of 25.8 per cent. These latter figures give some idea of the rate of aging and the amount of absorption which took place. During this period the time of set was retarded from that where the oxide was entirely unusable to that where it could be mixed in batches of about roo pounds and applied to panels. There is a marked difference in setting time between large and small batches if there is any appreciable amount of heat developed during or shortly after mixing, as this heat accelerates the set, and with large masses of mix with relatively small surface, the rise in temperature is greater, due to less heat loss through radiation, than with the smaller masses of relatively greater surface.

There has been a tendency on the part of caustic magnesia users to demand a maximum and minimum ignition loss. This is based upon the idea that this would show either that the one had not been overburned and hence contained some residual carbonic acid (thought to be combined with the lime present) or else had been properly aged and absorbed the demanded amount of gas (or moisture). If the results of the carbonic acid and ignition loss determinations in Table 3 are compared with the physical properties of the corresponding oxides, the lack of a basis for any such $53421^{\circ}-23-2$ 
demand is evident. Properly burned oxide does not require aging and may have an amount of residual gas considerably below the minimum requirement, while the low-burned oxides will have far too great an ignition loss, after proper aging, to meet the demands, though they may then have satisfactory physical properties.

At the present time the results of these calcining experiments at the bureau lead to the belief that the greatest cementing value would be obtained from magnesites, if they could be burned in a state of fine division, at temperatures of $700^{\circ} \mathrm{C}$. or below. This would produce an oxide almost as active toward water as quicklime that would require the addition of a retarder. This would reduce the speed but not diminish the final amount of reaction of the oxide with the chloride. It should be borne in mind that calcined gypsum and even Portland cement require the addition of a foreign material to retard their activity sufficiently to allow of their use. The caustic oxides on the market are rendered usable by calcining at higher temperatures, or by long-continued heating or aging after calcining, all three of which render part of the oxide less active.

\section{FINENESS AND SPECIFIC GRAVITY.}

Table I, which gives the results of the sieving analysis, specific gravity, and weight per cubic foot, presents some matters of interest. It has been proposed, and rightly so, to include a requirement for fineness in specifications covering the purchase of caustic magnesia. Undoubtedly the finer the product the more complete the reaction with the chloride, and hence the greater bond developed. But the difficulty with placing such a requirement in a specification would be that of enforcing it. While the specific gravity is rather high, as high on the average as that of Portland cement, yet it occupies but about half the volume of the latter. It appears to be much finer grained, and the grains are amorphous, porous, and readily agglomerate into larger masses, which will not pass through the meshes of the sieve. Hence, unless wet sieving were resorted to, it would be useless to put into a specification a requirement demanding the use of 200-mesh sieve. In certain cases it is also difficult to have the oxide pass through the roo-mesh sieve, but this is rather seldom, and a little persistency on the part of the operator, coupled with the proper jarring, will bring about a satisfactory result in the roo-mesh sieve. A requirement for the latter would demand at least 95 per cent passing, and even 97 per cent would not entail undue costs in grinding. 
The specific gravity of a well-calcined ore, not aged too long, will be about 3.20. If somewhat underburned, the gravity will be between the latter figure and 3.00. Aging will reduce the latter considerably.

The bulk volume has been used in proportioning mixtures for flooring and stucco. The values given in Table I indicate to a degree the error which may result from such proportioning. Indeed the error may be considerably more than that indicated. The method used in making this determination consisted in placing a cubical one-eighth cubic foot measure 6 inches below a cone having a I-inch outlet and holding about 35 per cent more than the measure. The oxide was placed in the funnel and then allowed to flow out by withdrawing a slide which had closed it. The measure was then filled to overflowing and the excess struck off without jarring to obtain the loose volume, and jarred to no further settling and then struck off to obtain the packed volume. The loose volume could be made to vary as much as I 5 per cent, depending upon whether the funnel was filled by taking the oxide directly from the bag or container when it had settled or by filling from a partially filled container when it had been well shaken up or "fluffed" with air. The loose volume given in the table was obtained by the latter procedure, as it tended to give more concordant results. In practice, the method of filling directly from the container would be followed, and hence the bulk volume obtained would be intermediate between the indicated loose and packed weight per cubic foot. Those accustomed to do their proportioning by volume should note the two sets of values. Preferably proportioning of mixtures should be made by weight.

\section{INDEX OF REFRACTION.}

It has been proposed to determine the degree of burning of magnesite by the index of refraction of the resulting oxide. This index can be determined sufficiently close in this respect by the use of a microscope and a set of solutions having indices from $\mathrm{r} .60$ to $\mathrm{I} .75$, the index of each solution differing from the previous or succeeding one in the series by o.or. The observation is made by placing grains of the oxide in a drop of solution on a slide and noting the Becke line. ${ }^{1}$ These observations were made on the oxides produced in this investigation, and the results indicate that

${ }^{1}$ Consult for details, especially "The Methods of Petro. Microsc. Research," by F. E. Wright, Carnegie Inst., Washington, Pub. 158, 73, I9Ir. Also "Microscopical Petrography," by the same author in Journal of Geology, Sept.-Oct., Ig12. Such works as "Optical Mineralogy," by Winchell, or "Optical Properties of Crystals," by Grath-Jackson, or "Elementary Chemical Microscopy," by Chamot, may also be consulted. 
the method has promise for a plant-control method. The indices found are shown in Table 4.

TABLE 4.-Index of Refraction.

\begin{tabular}{|c|c|c|c|}
\hline Magnesite. & Size. & Burned at- & $\begin{array}{l}\text { Index of re- } \\
\text { fraction. }\end{array}$ \\
\hline A....... & $\begin{array}{r}1 \\
2-3\end{array}$ & $\begin{array}{c}\circ \\
900 \\
800\end{array}$ & $\begin{array}{l}1.71 \\
1.70\end{array}$ \\
\hline B... & $\begin{array}{l}1 \\
2 \\
3\end{array}$ & $\begin{array}{l}900 \\
800 \\
700\end{array}$ & $\begin{array}{l}1.70 \\
1.69 \\
1.68\end{array}$ \\
\hline C..... & $\begin{array}{l}1 \\
1 \\
2 \\
3\end{array}$ & $\begin{array}{r}1,100 \\
900 \\
800 \\
750\end{array}$ & $\begin{array}{l}1.71 \\
1.69 \\
1.67 \\
1.60\end{array}$ \\
\hline D..... & $\begin{array}{l}1 \\
2 \\
3\end{array}$ & $\begin{array}{l}900 \\
850 \\
800\end{array}$ & $\begin{array}{l}1.69 \\
1.68 \\
1.67\end{array}$ \\
\hline
\end{tabular}

These indices represent in any one case the index of the predominating constituent, or, better, of the major portion of the material on the slide. For instance, if a comparatively large piece of ore were given a calcination at approximately $\mathrm{I}, \mathrm{IOO}^{\circ}$ of a not too long duration, it would produce a piece of oxide, the exterior of which would have an index of approximately $1.7 \mathrm{I}$, while the interior would have an index considerably lower. Depending upon the degree of calcination throughout the piece, a slide made by crushing and properly reducing the piece would show particles of indices varying from I.60, the index of very low-burned oxide, to about I.7I, the index of oxide burned at approximately $\mathrm{I}, \mathrm{IOO}^{\circ}$. A small piece of ore burned throughout at $\mathrm{I}, \mathrm{IOO}^{\circ}$ will show after crushing practically all particles to have an index of $\mathrm{r} .7 \mathrm{r}$. The oxides used in this investigation were very uniform in the indices noted, except for the low-burned ones. Hence, the figures given above in the latter cases are those for a varying but major portion of the oxide, while with the higher burned oxide they represent practically the entire oxide.

The method consequently will seem to help the calciner determine the degree and uniformity of burning. In the hands of the purchaser it would serve the same purpose, but, unfortunately, does not serve well to bring out the effects of storage.

\section{TIME OF SET.}

The results of the time-of-set determinations given in Table 5 are not as conclusive as might be expected in so far as the effect of the degree of burning is concerned. But the statement above 


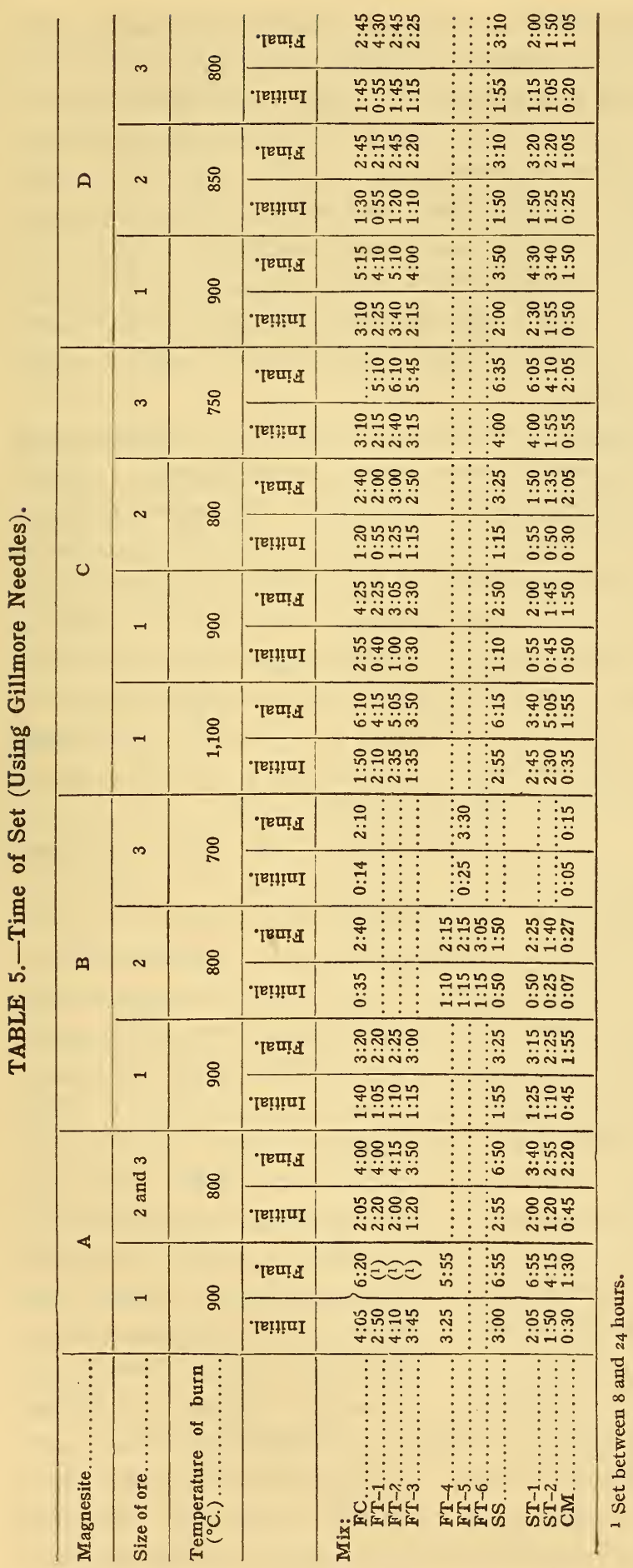


in regard to the length of time of aging should be remembered. The oxide produced from magnesite $\mathrm{C}$, burned at 750 and $800^{\circ} \mathrm{C}$., and from $\mathrm{D}$, burned at 800 and $850^{\circ} \mathrm{C}$., had to be aged before it was sufficiently slow setting to be used. The few physical tests obtained from magnesite $\mathrm{B}$, burned at $700^{\circ} \mathrm{C}$., was due to the attempt to use it without aging, the quick set resulting in obtaining very few and very poorly made test specimens. It can be stated that the time of set decreases with a decrease in the temperature of burning. This is due to the fact, as stated before, that low burning produces a very active oxide which reacts rapidly with the chloride.

It is evident that magnesite $\mathrm{A}$ produced the slower setting oxide at either of the two temperatures at which it was burned. It will be recalled that this is a crystalline magnesite. It appears, therefore, that this type of oxide is more readily overburned or more easily burned at a lower tempertaure than the amorphous ones. It apparently permits a more ready access of heat to the interior of the piece and a more uniform burning than the amorphous variety. In the latter case the exterior of the piece seems to form an insulating layer, hence, crushing to a smaller size before burning and heating for a longer time at any temperature is required for this type than for the crystalline type.

The time of set of the several oxides from the amorphous variety differs somewhat. For the same size of ore or temperature of burning, magnesite D was generally somewhat the slower setting of the three oxides from this type, and B somewhat slower than C. However, it should not be assumed that oxides from these ores would always have the same relative setting times, as it would be readily possible to so size the ore or change the conditions of burning that the time of either would be changed. The outstanding feature of these determinations, however, is the different time of setting of different mixtures in which the same magnesite is used. An extreme in this respect is represented by the mixture in which magnesite $\mathrm{A}$ burned at $900^{\circ} \mathrm{C}$. was used. In these, the time of set ranged from 30 minutes to 4 hours and Io minutes. In the mixture which developed the former setting time, I I per cent of oxide was used, while the mixture developing the slower setting time contained 35 per cent. Hence, the higher per cent of cement or reacting material produced the slower set. An examination of other data will also show that the controlling feature in the time of set is not so much the amount of oxide present as the kind and amount of other aggregate in the mixture. 
If a quick-setting oxide has been purchased it may be possible to use it by a simple rearrangement of the mixture in which it is to be used, provided, of course, that the other physical properties desired are not deleteriously affected.

Not sufficient data are at hand to permit of drawing a conclusion as to which constituent of the mixes has been the most active in influencing the set. It is clearly evident that the flooring mixes, even though they contain approximately, on an average, three times the amount of oxide that the stuccos do, are decidedly slower setting. The striking difference between the two types of mixes is, of course, the very small amounts of fibrous materials and the large amounts of sand in the stucco. That the fibrous material may affect the setting time markedly is evidenced by the fact that the CM mix, which is free of this constituent, has invariably the most rapid setting time. In view of the fact that this investigation was primarily for the purpose of determining certain properties of caustic magnesia, the study was not broadened to include the question of the effect of those materials with which it might be used, excepting in a very general way. Such an investigation must be a separate one, and is one urgently needed. Hence, the data are too meager to permit of any extended discussion of the properties of the mixes from any other viewpoint than that of the oxide.

\section{STRENGTH OF SPECIMENS.}

Three types of test specimen were used in determining the strength developed by the various mixtures of the several oxides. The tensile specimen was similar to that used in testing Portland cement and is familiar to all engaged in testing structural materials. The compression test specimen was a cylinder 2 inches in diameter and 4 inches high. The results of the compression tests are not shown in the tables as they add very little to the information furnished by the other strength tests. In view of there being no apparent advantage in this type of specimen and the fact that more time and material are required, their use will be discontinued. The transverse test piece was a bar $1 / 2$ by 2 by I 3 inches. This was broken by placing on supports Io inches apart and applying a load at the center, placing in compression (against the knife edge or bearing applying the load) the side uppermost during molding. A half of each bar, after breaking the full bar, was broken on supports 5 inches apart, the load being applied on the surface opposite to that used when testing 
the full length bar. The data collected from tests of the half bars have been omitted. In nearly every instance the modulus of rupture on the half bar was greater than that on the full length. If the specimen had been homogeneous, the modulus of rupture resulting from the test with a 5 -inch span should have been the same as that with a ro-inch span. Therefore, troweling and exposure of one surface to the atmosphere during the first 24 hours produced greater strength in that side of the specimen. However, the results indicate that greater uniformity of tests may be obtained by breaking the specimens with the troweled side in compression. The tensile and compression strength specimens were allowed to remain in the mold for 24 hours with the top and bottom surfaces covered with glass plates. The transverse bar was left in the mold for the same length of time, but the upper surface was exposed to the atmosphere. All specimens thereafter were stored in the air of the laboratory until tested, except two sets of the three kinds made of the stucco mixtures and indicated in the tables as stored in " $\mathrm{H}$ " and " $\mathrm{D}$."

These forms of aging were followed to obtain some idea of how the stucco mixes would behave if submitted to the action of an alternate wetting and drying after a preliminary period of normal aging. Such procedure is suggested by the fact that stuccos may be subjected to heavy rains in their early history with possible consequent damage of the cement, if of the type that is likely to be affected by severe wetting. In the " $\mathrm{H}$ " and " $\mathrm{D}$ " storage, the specimens were stored as usual for 24 hours in the mold, and after 20 days storage in the air they were placed in water for 24 hours. The " $H$ " stored specimens were then placed for 24 hours in a damp closet, the humidity of which was from 90 to 95 per cent (saturated); then the operation of wetting and drying was repeated twice and after a last day (28 days after molding) in the damp closet, the test pieces were broken. The " $\mathrm{D}$ " stored specimens were similarly treated, but were stored after each wetting in a closet with an average humidity of 50 per cent, which is approximately an average humidity for Washington.

The material for the specimens, except in the CM mixes, was dry mixed in a ball mill, free of balls, in amounts of about 90 pounds total for the stucco and 55 pounds for the flooring mixes. These amounts of dry mixtures were then mixed with the magnesium chloride solution in a mortar box and used in making the service panels as well as the laboratory test pieces. Consequently the latter were made of the same mortar as was used in the panels. 
The CM mix, being solely a laboratory mix, was mixed on a glass plate by hand, kneading in amounts of about a thousand grams of dry material. The consistency used is indicated by the data in Table 6. Attempts were made to control this factor by the use of pins, suggested by the Dow Chemical Co. ${ }^{2}$ These of a certain weight and character are used somewhat like Gilmore needles, but being of large diameter, proved entirely unsatisfactory on account of the extreme stickiness of the mortars. The same difficulties were encountered with the Vicat plunger and the ball method of determining consistency. The consistency obtained by the use of the weight of chloride given in the table produced a mortar wetter than would ordinarily be used for laboratory work, but compared very closely with that used by a workman in actual practical application.

TABLE 6.-Amounts of Chloride Used in the Different Mixes.

\begin{tabular}{|c|c|c|c|c|c|}
\hline \multirow{2}{*}{ Mix. } & \multirow{2}{*}{$\begin{array}{c}\mathrm{Cc} 22^{\circ} \mathrm{B} . \\
\text { solution per } \\
1,000 \text { grams } \\
\text { dry mix. }\end{array}$} & \multicolumn{2}{|c|}{$\begin{array}{c}\text { Pounds } 22^{\circ} \mathrm{B} \text {. solution } \\
\text { per- }\end{array}$} & \multicolumn{2}{|c|}{$\begin{array}{l}\text { Pounds anhydrous salt } \\
\text { per- }\end{array}$} \\
\hline & & $\begin{array}{l}\text { Pound } \\
\text { mix. }\end{array}$ & $\begin{array}{c}\text { Pound } \\
\text { magnesite. }\end{array}$ & $\begin{array}{l}\text { Pound } \\
\text { mix. }\end{array}$ & $\begin{array}{c}\text { Pound } \\
\text { magnesite. }\end{array}$ \\
\hline 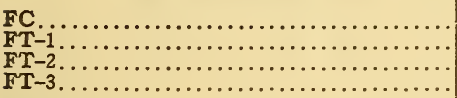 & $\begin{array}{l}860 \\
588 \\
779 \\
789\end{array}$ & $\begin{array}{r}1.014 \\
.693 \\
.917 \\
.932\end{array}$ & $\begin{array}{l}2.90 \\
1.98 \\
2.63 \\
2.07\end{array}$ & $\begin{array}{l}0.204 \\
.139 \\
.183 \\
.187\end{array}$ & $\begin{array}{l}0.58 \\
.40 \\
.53 \\
.42\end{array}$ \\
\hline 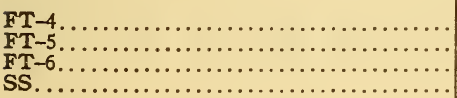 & $\begin{array}{l}509 \\
786 \\
585 \\
504\end{array}$ & $\begin{array}{l}.600 \\
.925 \\
.690 \\
.593\end{array}$ & $\begin{array}{l}2.40 \\
3.70 \\
4.60 \\
3.96\end{array}$ & $\begin{array}{l}.121 \\
.186 \\
.139 \\
.119\end{array}$ & $\begin{array}{l}.48 \\
.74 \\
.93 \\
.80\end{array}$ \\
\hline $\begin{array}{l}\text { ST }-1, \ldots \ldots \ldots \ldots \ldots \ldots \\
\text { ST }-2 \ldots \ldots \ldots \ldots \ldots \cdots \cdots \\
\text { CM. }\end{array}$ & $\begin{array}{l}266 \\
290 \\
153\end{array}$ & $\begin{array}{l}.313 \\
.342 \\
.180\end{array}$ & $\begin{array}{l}3.13 \\
2.28 \\
1.64\end{array}$ & $\begin{array}{l}.063 \\
.069 \\
.036\end{array}$ & $\begin{array}{l}.63 \\
.46 \\
.33\end{array}$ \\
\hline
\end{tabular}

The above used with each caustic magnesia excepting the following:

\begin{tabular}{|c|c|c|c|c|c|c|c|}
\hline \multirow{2}{*}{ Mix. } & \multirow{2}{*}{$\begin{array}{l}\mathrm{Cc} 22^{\circ} \mathrm{B} . \\
\text { solution per } \\
1,000 \text { grams } \\
\text { dry mix. }\end{array}$} & \multicolumn{2}{|c|}{$\begin{array}{l}\text { Pounds } 22^{\circ} \mathrm{B} \text {. solution } \\
\text { per- }\end{array}$} & \multicolumn{4}{|c|}{ Pounds anhydrous sait per- } \\
\hline & & $\begin{array}{l}\text { Pound } \\
\text { mix. }\end{array}$ & $\begin{array}{c}\text { Pound } \\
\text { magnesite. }\end{array}$ & $\begin{array}{l}\text { Pound } \\
\text { mix. }\end{array}$ & $\begin{array}{c}\text { Pound } \\
\text { magnesite. }\end{array}$ & MgO. & $\begin{array}{c}\text { Burned } \\
\text { at- }\end{array}$ \\
\hline FT-1. & 581 & 0.685 & 1.96 & 0.138 & 0.39 & $\frac{\mathrm{A}}{\mathrm{B}}$ & $\begin{array}{l}-800 \\
900\end{array}$ \\
\hline $\begin{array}{l}\text { FC... } \\
\text { FT }-4 . \\
\text { SS... }\end{array}$ & $\begin{array}{l}960 \\
543 \\
668\end{array}$ & $\begin{array}{r}1.128 \\
.636 \\
.646\end{array}$ & $\begin{array}{l}3.22 \\
2.54 \\
4.31\end{array}$ & $\begin{array}{l}.227 \\
.128 \\
.130\end{array}$ & $\begin{array}{l}.65 \\
.51 \\
.87\end{array}$ & $\begin{array}{l}\text { C } \\
\text { B } \\
\text { C }\end{array}$ & $\begin{array}{r}1,100 \\
800 \\
750\end{array}$ \\
\hline ST-2.. & 266 & .313 & 2.09 & .063 & .42 & C & 800 \\
\hline CM. & 135 & .159 & 1.45 & .032 & .29 & C & 1,100 \\
\hline CM. & 146 & .172 & 1.56 & .035 & .31 & C & 750 \\
\hline CM... & 142 & .167 & 1.52 & .034 & .31 & $\mathrm{D}$ & $\begin{array}{l}900 \\
850\end{array}$ \\
\hline
\end{tabular}

${ }^{2}$ Magnesium Chloride Service Bulletin No. 6, Dow Chemical Co., Midland, Mich. This corporation has distributed a series of mimeogra phed reports dealing with magnesium oxychloride products and their testing, which are very valuable. 
TABLE 7.-Tensile and Transverse Strengths.

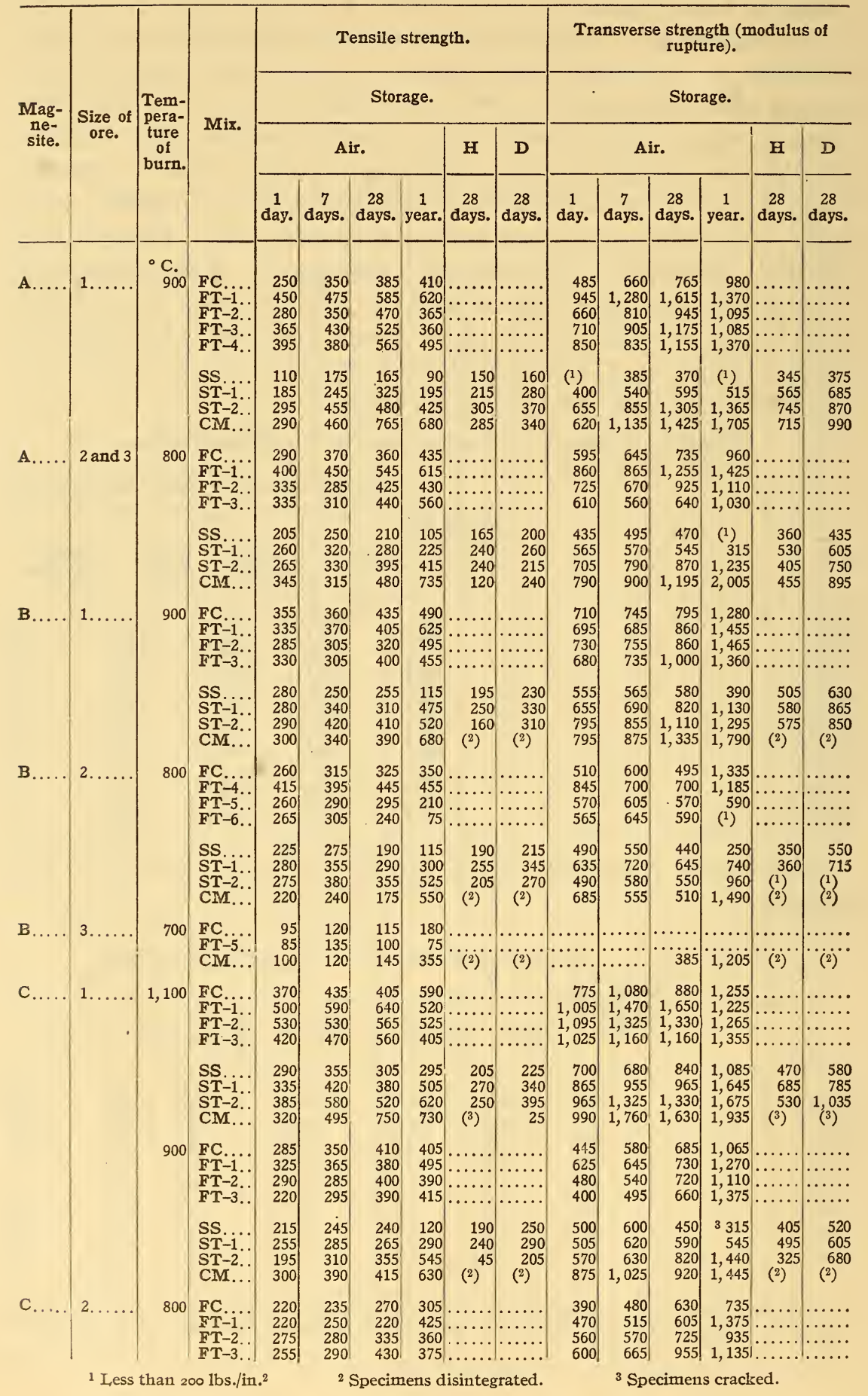


TABLE 7.-Tensile and Transverse Strengths-Continued.

\begin{tabular}{|c|c|c|c|c|c|c|c|c|c|c|c|c|c|c|c|}
\hline \multirow{4}{*}{$\begin{array}{c}\text { Mag- } \\
\text { ne- } \\
\text { site. }\end{array}$} & \multirow{4}{*}{$\begin{array}{l}\text { Size of } \\
\text { ore. }\end{array}$} & \multirow{4}{*}{$\begin{array}{l}\text { Tem- } \\
\text { pera- } \\
\text { ture } \\
\text { of } \\
\text { burn. }\end{array}$} & \multirow{4}{*}{ Mix. } & \multicolumn{6}{|c|}{ Tensile strength. } & \multicolumn{6}{|c|}{$\begin{array}{l}\text { Transverse strength (modulus of } \\
\text { rupture). }\end{array}$} \\
\hline & & & & \multicolumn{6}{|c|}{ Storage. } & \multicolumn{6}{|c|}{ Storage. } \\
\hline & & & & \multicolumn{4}{|c|}{ Air. } & $\mathrm{H}$ & $\mathrm{D}$ & \multicolumn{4}{|c|}{ Air. } & \multirow{2}{*}{$\frac{\mathrm{H}}{\mathrm{28}}$} & \multirow{2}{*}{$\frac{\mathrm{D}}{\mathrm{2}}$} \\
\hline & & & & $\begin{array}{c}1 \\
\text { day. }\end{array}$ & $\begin{array}{c}7 \\
\text { days. }\end{array}$ & $\begin{array}{l}28 \\
\text { days. }\end{array}$ & $\begin{array}{c}1 \\
\text { year. }\end{array}$ & $\begin{array}{c}28 \\
\text { days. }\end{array}$ & $\begin{array}{c}28 \\
\text { days. }\end{array}$ & $\begin{array}{c}1 \\
\text { day. }\end{array}$ & $\begin{array}{c}7 \\
\text { days. }\end{array}$ & $\begin{array}{c}28 \\
\text { days. }\end{array}$ & $\begin{array}{c}1 \\
\text { year. }\end{array}$ & & \\
\hline & $2 .$. & 800 & $\begin{array}{l}\text { SS... } \\
\text { ST-1. } \\
\text { ST-2. } \\
\text { CM... }\end{array}$ & $\begin{array}{l}135 \\
190 \\
165 \\
170\end{array}$ & $\begin{array}{l}185 \\
210 \\
200 \\
225\end{array}$ & $\begin{array}{l}130 \\
235 \\
185 \\
200\end{array}$ & $\begin{array}{r}45 \\
90 \\
405 \\
520\end{array}$ & $\begin{array}{r}170 \\
150 \\
45 \\
60\end{array}$ & $\begin{array}{r}180 \\
175 \\
90 \\
180\end{array}$ & $\begin{array}{l}285 \\
365 \\
355 \\
445\end{array}$ & $\begin{array}{l}345 \\
415 \\
420 \\
635\end{array}$ & $\begin{array}{l}260 \\
435 \\
445 \\
515\end{array}$ & \begin{tabular}{|c|}
$(1)$ \\
${ }^{(1)}$ \\
1,005 \\
1,500
\end{tabular} & $\begin{array}{l}280 \\
310 \\
(1) \\
(1)\end{array}$ & $\begin{array}{l}315 \\
405 \\
215 \\
(1)\end{array}$ \\
\hline & 3. & 750 & $\begin{array}{l}\text { FC.... } \\
\text { FT-1. } \\
\text { FT-2. } \\
\text { FT-3. }\end{array}$ & $\begin{array}{l}125 \\
190 \\
160 \\
190\end{array}$ & $\begin{array}{l}190 \\
280 \\
230 \\
250\end{array}$ & $\begin{array}{l}205 \\
325 \\
260 \\
335\end{array}$ & $\begin{array}{l}160 \\
500 \\
225 \\
335\end{array}$ & & & $\begin{array}{l}280 \\
495 \\
345 \\
435\end{array}$ & $\begin{array}{l}395 \\
620 \\
435 \\
580\end{array}$ & $\begin{array}{l}450 \\
870 \\
550 \\
805\end{array}$ & $\begin{array}{r}445 \\
1,130 \\
545 \\
970\end{array}$ & & $\begin{array}{l}\cdots . . \\
\cdots \cdots \\
\cdots \cdots \\
\cdots \cdots\end{array}$ \\
\hline & & & $\begin{array}{l}\text { SS... } \\
\text { ST-1. } \\
\text { ST-2.. } \\
\text { CM... }\end{array}$ & $\begin{array}{r}75 \\
100 \\
150 \\
210\end{array}$ & $\begin{array}{l}115 \\
160 \\
230 \\
345\end{array}$ & $\begin{array}{l}105 \\
135 \\
230 \\
470\end{array}$ & $\begin{array}{r}70 \\
115 \\
165 \\
570\end{array}$ & $\begin{array}{r}70 \\
110 \\
170 \\
315\end{array}$ & $\begin{array}{r}90 \\
120 \\
180 \\
365\end{array}$ & $\begin{array}{r}(1) \\
240 \\
295 \\
540\end{array}$ & $\begin{array}{l}275 \\
355 \\
495 \\
965\end{array}$ & $\begin{array}{r}(1) \\
340 \\
415 \\
1,135\end{array}$ & $\begin{array}{l}(1) \\
280 \\
355 \\
1,755\end{array}$ & \begin{tabular}{|l|}
$(1)$ \\
$(1)$ \\
405 \\
805
\end{tabular} & $\begin{array}{l}(1) \\
255 \\
370 \\
1,350\end{array}$ \\
\hline & 1. & soo & $\begin{array}{l}\text { FC... } \\
\text { FT-1. } \\
\text { FT-2. } \\
\text { FT-3. }\end{array}$ & $\begin{array}{l}370 \\
470 \\
445 \\
400\end{array}$ & $\begin{array}{l}400 \\
610 \\
500 \\
515\end{array}$ & $\begin{array}{l}425 \\
615 \\
570 \\
575\end{array}$ & $\begin{array}{l}445 \\
465 \\
485 \\
390\end{array}$ & & & $\begin{array}{r}800 \\
1,170 \\
1,020 \\
1,005\end{array}$ & $\begin{array}{r}910 \\
1,415 \\
1,220 \\
1,265\end{array}$ & $\begin{array}{r}940 \\
1,690 \\
1,400 \\
1,650\end{array}$ & $\begin{array}{l}1,255 \\
1,440 \\
1,105 \\
1,080\end{array}$ & & \\
\hline & & & $\begin{array}{l}\text { SS.... } \\
\text { ST-1. } \\
\text { ST-2.. } \\
\text { CM... }\end{array}$ & $\begin{array}{l}330 \\
300 \\
360 \\
345\end{array}$ & $\begin{array}{l}440 \\
350 \\
500 \\
505\end{array}$ & $\begin{array}{l}510 \\
345 \\
500 \\
640\end{array}$ & $\begin{array}{l}435 \\
490 \\
535 \\
765\end{array}$ & $\begin{array}{r}270 \\
245 \\
190 \\
(2)\end{array}$ & $\begin{array}{l}375 \\
380 \\
370 \\
(2)\end{array}$ & $\begin{array}{r}750 \\
760 \\
890 \\
1,360\end{array}$ & $\begin{array}{r}940 \\
865 \\
1,000 \\
1,850\end{array}$ & $\begin{array}{r}1,055 \\
820 \\
1,215 \\
2,120\end{array}$ & $\begin{array}{l}1,145 \\
1,440 \\
1,500 \\
1,740\end{array}$ & $\begin{array}{c}630 \\
700 \\
695 \\
(3)\end{array}$ & $\begin{array}{r}875 \\
1,015 \\
940 \\
3550\end{array}$ \\
\hline & 2 & 850 & $\begin{array}{l}\text { FC } \\
\text { FT- } 1 . \\
\text { FT-2. } \\
\text { FT }-3 .\end{array}$ & $\begin{array}{l}280 \\
205 \\
325 \\
305 \\
\end{array}$ & $\begin{array}{l}335 \\
240 \\
350 \\
340\end{array}$ & $\begin{array}{l}415 \\
430 \\
505 \\
480\end{array}$ & $\begin{array}{l}370 \\
650 \\
355 \\
505\end{array}$ & & & $\begin{array}{l}620 \\
575 \\
735 \\
600\end{array}$ & $\begin{array}{r}975 \\
845 \\
1,100 \\
950\end{array}$ & $\begin{array}{l}1,035 \\
1,115 \\
1,200 \\
1,080\end{array}$ & $\begin{array}{l}1,125 \\
1,695 \\
1,040 \\
1,450\end{array}$ & & : \\
\hline & & & $\begin{array}{l}\text { SS... } \\
\text { ST-1. } \\
\text { ST-2.. } \\
\text { CM... }\end{array}$ & $\begin{array}{l}260 \\
225 \\
220 \\
245\end{array}$ & $\begin{array}{l}285 \\
250 \\
235 \\
325\end{array}$ & $\begin{array}{l}335 \\
440 \\
425 \\
305\end{array}$ & $\begin{array}{l}150 \\
530 \\
595 \\
720\end{array}$ & $\begin{array}{c}125 \\
225 \\
130 \\
(3)\end{array}$ & $\begin{array}{c}180 \\
310 \\
135 \\
\left({ }^{3}\right)\end{array}$ & $\begin{array}{l}480 \\
505 \\
555 \\
845\end{array}$ & $\begin{array}{l}545 \\
670 \\
795 \\
860\end{array}$ & $\begin{array}{r}860 \\
1,085 \\
1,015 \\
815\end{array}$ & $\begin{array}{r}420 \\
1,350 \\
1,490 \\
1,940\end{array}$ & $\begin{array}{c}360 \\
510 \\
(1) \\
(3)\end{array}$ & $\begin{array}{c}530 \\
790 \\
430 \\
(3)\end{array}$ \\
\hline & & 800 & $\begin{array}{l}\text { FC... } \\
\text { FT-1. } \\
\text { FT-2. } \\
\text { FT-3.. }\end{array}$ & $\begin{array}{l}300 \\
295 \\
265 \\
285\end{array}$ & $\begin{array}{l}405 \\
265 \\
345 \\
310\end{array}$ & $\begin{array}{l}435 \\
395 \\
495 \\
500\end{array}$ & $\begin{array}{l}480 \\
535 \\
375 \\
400\end{array}$ & & & $\begin{array}{l}580 \\
590 \\
770 \\
805\end{array}$ & $\begin{array}{l}975 \\
900 \\
870 \\
860\end{array}$ & $\begin{array}{r}895 \\
1,110 \\
1,105 \\
1,120\end{array}$ & $\begin{array}{l}1,055 \\
1,740 \\
1,135 \\
1,085\end{array}$ & : & \\
\hline & & & $\begin{array}{l}\text { SS.... } \\
\text { ST-1. } \\
\text { ST-2.. } \\
\text { CM... }\end{array}$ & $\begin{array}{l}200 \\
235 \\
230 \\
240\end{array}$ & $\begin{array}{l}205 \\
315 \\
290 \\
355\end{array}$ & $\begin{array}{l}170 \\
390 \\
490 \\
340\end{array}$ & $\begin{array}{l}135 \\
450 \\
435 \\
700\end{array}$ & $\begin{array}{r}95 \\
275 \\
235 \\
85\end{array}$ & $\begin{array}{l}165 \\
430 \\
320 \\
100\end{array}$ & $\begin{array}{l}395 \\
490 \\
470 \\
915\end{array}$ & $\begin{array}{r}450 \\
655 \\
700 \\
1,195\end{array}$ & $\begin{array}{r}375 \\
900 \\
1,205 \\
1,185\end{array}$ & $\begin{array}{r}335 \\
3915 \\
1,130 \\
1,920\end{array}$ & $\begin{array}{c}220 \\
605 \\
485 \\
(1)\end{array}$ & $\begin{array}{r}325 \\
1,075 \\
895 \\
780\end{array}$ \\
\hline
\end{tabular}

1 Less than 200 1bs./in. ${ }^{2}$

${ }^{2}$ Specimens disintegrated.

${ }^{3}$ Specimens cracked.

Table 6, giving the consistency, should be studied particularly in connection with Table 7 , showing the strengths. The consistency of the flooring mixes, neglecting mixes FT-5 and FT-6 which were designed only for an abnormally quick-setting lowburned oxide, as expressed by the relation between the chloride and magnesia, does not vary much. It is rather interesting, however, to note that mix FT-I, which has the least amount of chloride per unit of magnesia, more frequently gave a higher strength in tension or transverse than any of the other mixes. In the sanded mixes, those having the least chloride (CM and 
ST-2) gave higher results than those containing more chloride. But when the behavior of the specimens subjected to water is examined, it is very noticeable that the results are reversed. The CM mix was particularly liable to deteriorate rapidly and even disintegrate under these conditions while the SS and ST-I mixes, which per unit of magnesia contain from two to two and onehalf times as much chloride, withstood the water treatment very satisfactorily.

Viewed from the standpoint of Portland cement mortars, these results would possibly be explained, especially in the case of the CM mix, on the basis of poor proportioning. This particular mix contains 67 per cent standard Ottawa sand, which is composed of relatively large uniform sized grains, and 22 per cent very finegrained silica, and hence lacks the needed grading in sizes and is porous permitting of the penetration of water. This reasoning, however, is not valid in the case of mixes ST-I and ST-2 which contain the same amounts of coarse and fine material, the sole difference being that in one case 5 per cent of fine magnesia is replaced by an equal per cent of equally fine silica. But these two mixes differed about 50 per cent in the chloride per unit magnesia ratio and also materially in their resistance to the action of water. It would appear as though the difference in the resistance to the reaction of water must be looked for rather in the difference in the character of cementing material formed by the reaction of the chloride and the caustic magnesia. This is not thoroughly understood, but the result of the reaction is apparently a colloidal (jelly like) mass, which in certain cases is almost transparent, but is usually rendered translucent by the presence of unacted-upon grains of oxide and some of the fine aggregate. In the course of time, crystals of an oxychloride appear and extend more or less throughout the mass. Generally, however, the crystals do not appear in any great amount until at the end of a time greater than that at which the specimens (" $H$ " and " $D$ " stored) were tested. Hence, it was the gelatinous reaction product which was submitted to the action of the water. Such investigations as have been made of this reaction product show that its composition varies considerably, although the investigations do not show what causes these variations. ${ }^{3}$ The difference in the action of these rather similar mixes, in which possibly the greatest variable is the chloride-magnesia ratio, would apparently indicate that the change in this ratio produces reactions or cements which

${ }^{3}$ B. S. Circular No. 135 . 
differ materially. According to the results a low ratio produces a cement having higher strength, if subjected to air storage, than one resulting from the use of a higher ratio, but the cement produced by the former ratio is not as resistant to the action of water as is the one resulting from the use of the latter ratio.

It has been stated previously that a caustic magnesia, unsuitable in one mix, may be satisfactory in another. Figure I shows the very marked effect which the mix has upon the behavior of products containing the same magnesia, particularly the change in strength with aging. Mixes $\mathrm{CM}, \mathrm{ST}-2, \mathrm{FT}-2$, and $\mathrm{F} T-4$ containing magnesia $A$ increased in strength with age, but SS, ST-I, FT-I, and $\mathrm{F}$ T- 3 deteriorated after the 28 -day period. It will be remembered that a flooring panel of the mix FT-I, containing this magnesia, cracked and "dished" and was replaced by mix FT-4 which gave much more satisfactory results. Magnesite B, burned at $900^{\circ} \mathrm{C}$., behaved more uniformly in the different mixes than the others. In this group, mix SS alone deteriorated after the 28 -day period. Magnesite $\mathrm{D}$, burned at $900^{\circ} \mathrm{C}$., is unsuitable in the flooring mixtures used if the strengths continue to decrease as indicated, yet in the stucco mixtures it appears to be entirely satisfactory. The reason for this may be in the ratios of chloride to magnesia that are needed to give the better product. This ratio is governed largely by the mixtures, as a working consistency must be obtained, and in any certain mixture the required consistency may result in too much or too little chloride, whereas another mixture may demand a consistency which requires an amount of chloride solution that will give the proper ratio. The question of consistency is more complicated than in the case of Portland cement. With the latter, changes in consistency are the resultant of changes in the variable, liquid (water) and solid, but in the case of caustic magnesia cements, the liquid is not water, but a solution of a salt and both the salt and the water are essential to the reaction. Hence, the liquid phase may be varied in both the amount and concentration. This phase of the subject was considered in some detail in a previous paper by the bureau, ${ }^{4}$ which should be consulted for a further discussion. It should be noted, however, in the present cases that the consistencies with the exception of the CM mix were approximately the same so far as workability was concerned, and the concentration also the same. To have secured the same chloride-magnesia ratio would

4 Plastic magnesia cements; Bates and Young, Jour. Am. Cer. Soc., 4, No. 7; July, Ig2r. 
have required different concentration. This would have led into a study foreign to the present investigation and covered in the one just cited. So far as the CM mix is concerned, a chloride-
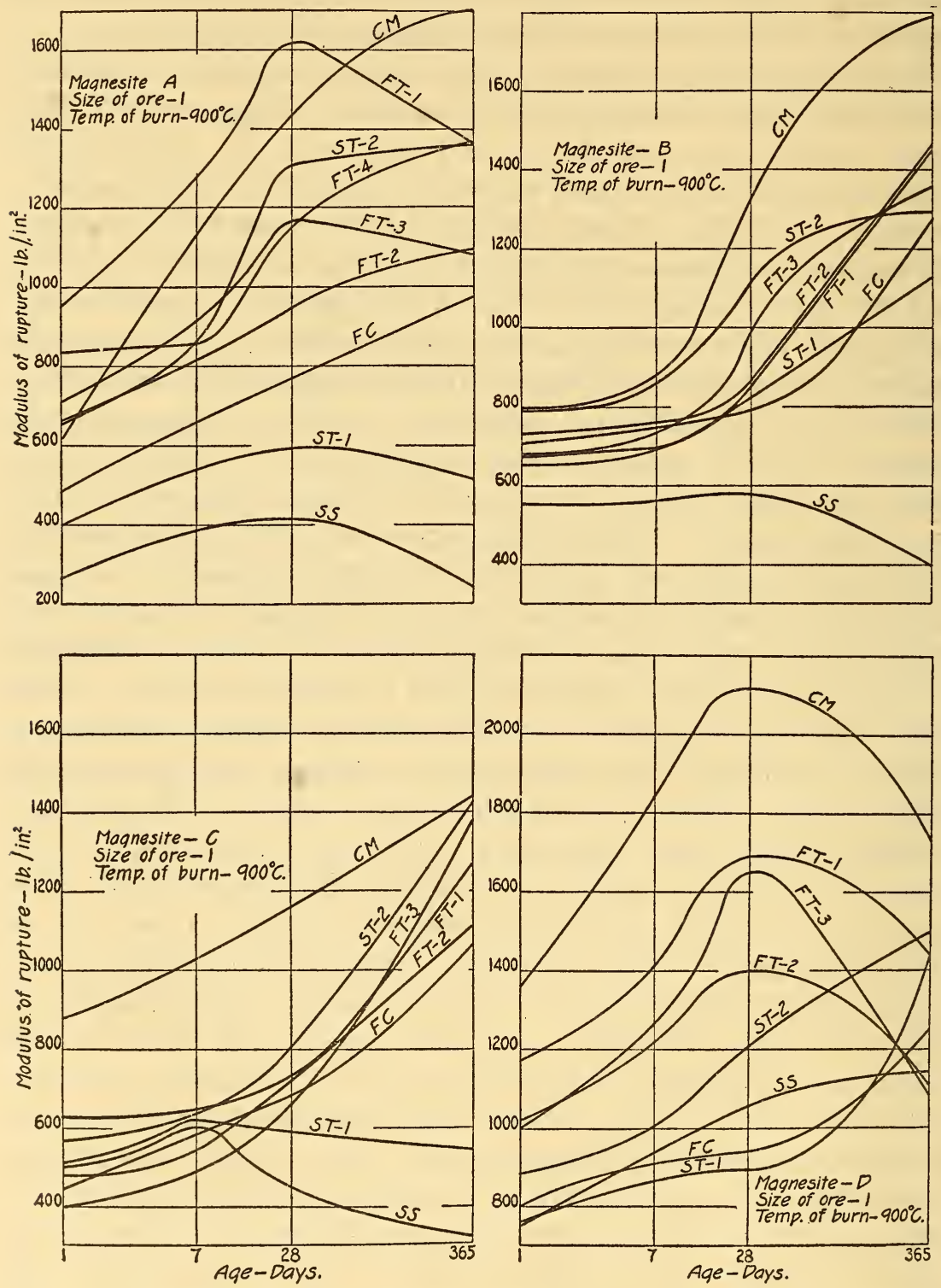

FIG. I.-Strength-age curves showing the marked influence of mix on the development of strength.

magnesia ratio comparable with the ratios used in the other mixes would have required so much solution of $22^{\circ} \mathrm{B}$. concentration that the consistency would have been entirely too wet. 
A comparison of the strengths developed by the different magnesias shows that the crystalline ore and the amorphous ore $D$ generally produced the higher testing specimens for all conditions of burning. From this it is not to be assumed that just as high a strength-producing oxide could not be produced from the other ores. The size of the shipments of ores did not permit of making burns to determine the optimum burning conditions for each ore. It appears, however, that the temperatures used approached the optimum more nearly for magnesites $\mathrm{A}$ and $\mathrm{D}$ than for $\mathrm{B}$ and $\mathrm{C}$. Figure 2 shows the variation resulting from the use of different ores which were burned and used under identical conditions. It
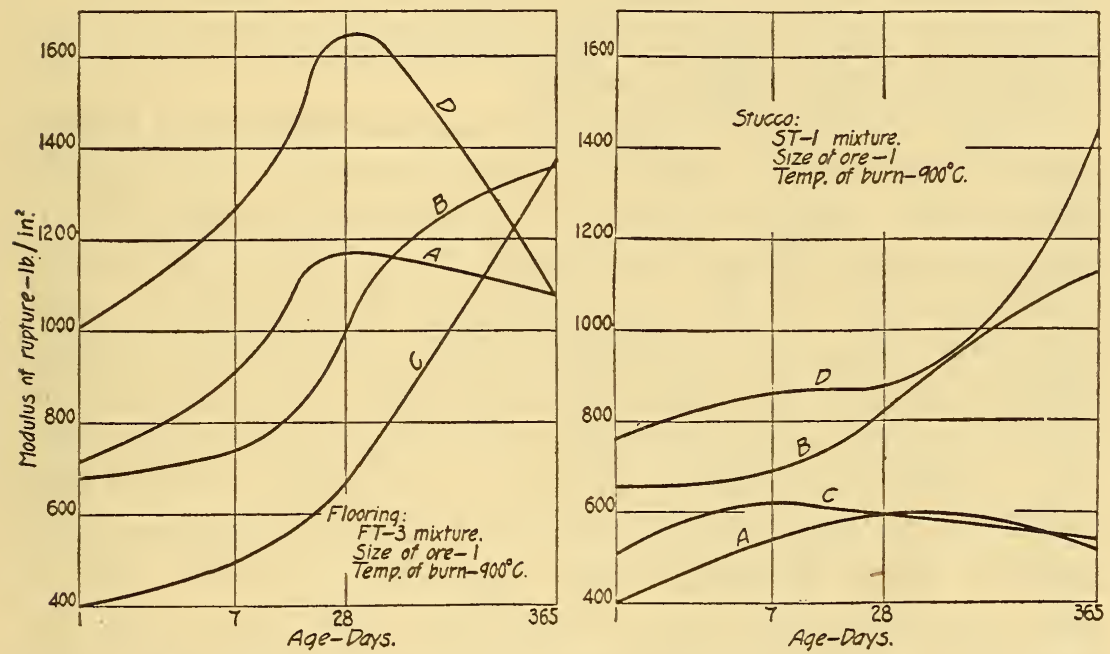

FIG. 2.-Strength-age curves showing the variation in strength properties resulting from the use of different ores which were subjected to identical conditionsduring the calcining and testing operations.

may be seen that the use of the various magnesites (A, B, C, and D) produced materials of widely different strengths and character of time-strength curves in both stucco and flooring mixtures. The results must not be construed as showing that oxides from either of the two latter deposits will always be inferior to that from the others.

The results do substantiate the contention frequently made and generally accepted, that each deposit of ore will quite likely require a different burning condition (temperature, size of raw material, length of time of burning, etc.) to produce the most satisfactory caustic oxide. Even a casual examination of the tables will confirm this. It is strikingly brought out by compar- 
ing the values for ore $\mathrm{C}$ burned at $\mathrm{I}, \mathrm{IOO}^{\circ}$ with those obtained by burning this ore at a lower temperature.

The tables should also be studied, having in mind both the strength developed by any particular oxide in the different mixes, and also comparing the same mix using oxide from the same ore but burned under different conditions. A study along the former line has been indicated before and it was noted how an oxide which has given an unsatisfactory time of set in one mix may be used in a different mix with eminently satisfactory results. The same applies to the strength which an oxide may develop. This may be very materially changed by variations in the mixing formula which do not make any changes in the amount of oxide used. It can also be noted that the higher percentages of oxide do not necessarily produce higher strength.

It should be noted in particular that the stucco and flooring mixtures produced two distinct types of products. This is clearly evident if the strength developed by the two are compared. In many cases the average stucco values are as high as the flooring results, though there may be present but from one-third to onehalf of the amount of cementing product. It might be contended that the results do not show that the flooring mixes could have the oxide reduced to an amount apparently equal to that of the stucco and still give a high testing product. The results obtained from mix FT-6 in the one case where such a lean mixture was used might be taken to indicate that such could be done. But the year results show that the test specimens from this mix are disintegrating. The flooring service panels of this mix were always too "soft" (easily abraded) to be considered of any particular value.

Comparing the strength, which any oxide from the same ore, but produced by calcination under different conditions, developed, it is noted that generally as the burning temperature was lower a lower strength was obtained. This is not so marked in the case of the oxide from the crystalline ore. This confirms results ${ }^{5}$ obtained in a previous investigation, which showed that this particular ore had a rather wide range of burning conditions under which it could be calcined and yet produce a good oxide.

The CM mix was designed as a laboratory mix for the purpose of seeing if it were possible to use a mix of this type for the routine testing of caustic oxides as an "acceptance" test. Such a mix should contain the least number of constituents, and all but the

${ }^{6}$ Plastic magnesia cements; Bates and Young, Jour. Am. Cer. Soc., 4, No. 7; July, I92I. 
oxide should be of constant physical properties and readily available in quantities. Hence, this mix contained but the oxide, fine silica, which is available in very large quantities as "silex," "I40-mesh silica," or "potters flint," and standard Ottawa sand, which is produced under the supervision of a special committee of the American Society of Civil Engineers, for testing Portland cement. In addition to these qualities, the mix should, in the form of test pieces, predict how the oxide which it contains would deport itself in other mixes, especially when the latter were used in practice. The results obtained in this investigation do not speak too highly for the use of this mix unless possibly accompanied by other tests. There were too many cases where it gave apparently similar results with two or more oxides, whereas the flooring or stucco mixes for the same oxides were distinctly different. Its tendency seemed to be to give higher results even with those oxides which gave low results with other mixes. Its susceptibility to deleterious action by the water treatment in the " $\mathrm{H}$ " and " $D$ " storage might be construed as in its favor as isolating oxide which would not give satisfactory stucco. But there are a number of cases in which this mix, under this storage condition, failed completely or nearly so while the same oxide in another mix was not affected or showed an increase in strength. However, a mix of this type is almost a necessity if an acceptance is demanded by the consumer. The geographical distance between the producer and the consumer hardly permits of the two using the same constituents of flooring or stucco mixes without excessive cost. Furthermore, the cost of testing under such conditions would be still further increased by the necessity of preparing, standardizing, and distributing asbestos, wood flour, color, sand, etc., just as now Ottawa sand is distributed. It would also be a rather difficult matter to standardize such materials as asbestos and wood flour and have them remain constant in their properties. But considered from the results of this present investigation, and others carried out elsewhere, a mix of this type could be used in a specification as a purchase requirement, provided"it was considered in connection particularly with the time of set and was used in making both the tension and transverse test pieces. These should develop a certain minimum strength at 24 hours and 7 days. The inclusion of a strength requirement for the same type of specimens at the age of 28 days, but having been subjected to a number of wettings, would be of value. 
The use of such a series of test pieces would be far more satisfactory as an acceptance test than the chemical requirements for lime, carbonic acid gas, and ignition loss, which now constitute almost the only acceptance requirements. But these test pieces could hardly be used as a criterion of how the oxide might deport itself with various aggregates. When it comes to preparing a working formula for the aggregates at hand, using a certain oxide, it would be necessary to try out several formulas by making and testing certain test pieces such as have been used in this investigation.

\section{VOLUME CHANGES.}

A set of three bars of the same size as those used in the determination of the transverse strength was made for the determination of the changes in length with age. The measurements were made with a Berry gauge over a ro-inch length. The initial measurements were made when the specimens had attained initial set, and later measurements were made at the end of I, 2, $4,7,28$, and 90 days and thereafter at three-month intervals. With the exception of the CM mix the material for the bars was taken from the mortar box in which had been prepared the mortar for the service panel. The specimens for the CM mix were prepared in the laboratory. The changes in length over a ro-inch length in two directions normal to one another were also made on the flooring and stucco panels with the same instruments and at the end of the same periods. The immense amount of data obtained from these measurements is not presented, but is on file in complete form at this bureau. Anyone desiring to examine these data or the results of the compression tests may do so. Here, again, the effects of degree of calcination and variation of mix stand out. It appears, however, that the heat treatment has a greater influence upon volume changes than the mix. Although there was considerable variation resulting from the different mixtures in which the magnesia was identical, practically all the test bars containing magnesia burned at $900^{\circ}$ or above expanded. In connection with this should be considered the fact that no failures in the test panels can be attributed directly to expansion. Test bars containing magnesia burned at 850 and $800^{\circ}$ expanded or contracted, depending upon the ore or mix. All bars containing magnesia burned at lower temperatures contracted at the earlier periods, but later some began to expand and at the end of a year showed comparatively a very large increase in length over the original. 
The outstanding feature is the very gieat difference between the amounts of change in the bars and in the panels. The latter, in the case of the flooring, were placed upon a finished concrete floor of a "ground floor" (but not a basement of the damp, poorly ventilated type) laid directly upon the earth. One part of the flooring is in a suite of rooms used as a laboratory for the inspection and testing of optical glass and the other part is placed in a passageway. The concrete was not roughened, but i 8 gauge expanded metal lath was placed upon it fastened at points 18 inches apart to wooden plugs driven into holes drilled in the concrete. After wetting down the concrete with a cream of chloride and oxide, the scratch coat was applied just covering the metal. At the end of 24 hours the top coat was applied. One panel of each mix was placed so as to receive considerable wear, while the other was placed toward the side of the room. The stucco was placed upon a hollow-tile penthouse on a roof. The tile was poorly laid, being composed of odd-sized hard and soft tile with wide cement mortar joints. When applying the stucco, the tile was first wet with a cream of oxide and chloride, then the scratch coat applied, and at the end of 24 hours the top coat applied. No attempt was made to obtain other than a "wooden float" finish.

It will be seen from the above procedure that the service panels were applied as in actual practice and consequently the scratch coats were restrained from expansion either by the metal lath or by the bond to the wall, and the top coat by the bond to the scratch coat. Hence the reason is evident for the large difference in changes between the laboratory and service measurements, as the bars from the former, after removal from the molds at the end of 24 hours, were placed upon their edges, supported at "quarter points" and entirely unrestrained. The disappointing feature of this part of the investigation is that there is no apparent fixed ratio between the laboratory and service measurements. It can only be stated that under the latter conditions the changes in length are much less than in the former. The condition of the panels does indicate that some reliance should be placed upon the laboratory measurements. Of two magnesites, that which shows the least change in a laboratory test should be chosen, but it would be difficult to say from the present tests what maximum limit should be used as suggesting possible future failure in service. Practically all the flooring panels, except those made of the low- 
burned oxides, which gave a far too soft floor for practical use, have become loose wholly or partially from the cement base, though they seldom warped or cracked. Granted that the method of placing the service panels was not one which would have been recommended in practice (roughening of the concrete would have been far more desirable) this condition does indicate that the stresses, due to volume changes, were large and likely caused the separation from the base.

Generally the magnitude of the changes of the stucco mixes is less than that of the flooring. The service panels of the former are in good condition, adhering well to the walls and showing no cracking, except that which occurred in the case of some of the panels containing quick-setting oxide. This cracking occurred at about the time of final set. The lower portion of several panels is upon a concrete beam upon which rests the tile wall. A crack appeared very shortly after placing at the junction of the concrete and tile. At the present time, the stucco is separating from the concrete. In general, however, the condition of the stucco on the panels is very good, far better, in fact, than one would expect from the laboratory results.

The flooring panels are not in as good a condition as are the stucco panels, but it is a question whether their faults should be laid upon the oxides or upon the mixtures used. Mix FT-I is in reality a suggested laboratory mixture possibly suitable for use in making acceptance tests. It unquestionably contains too much asbestos for use as a practical mixture. It gave with all oxides, the hardest floor, cracked in the cases of the use of oxides from magnesite $\mathrm{A}$ (burned at $800^{\circ}$ ) and $\mathrm{D}$ (burned at $800^{\circ}$ and $850^{\circ}$ ) but with the other oxides was fairly satisfactory, though showing a tendency to loosen from the cement, possibly due to the contraction as indicated by the measurements. The mixtures indicated by $\mathrm{F} T-2$ approached those used in commerce though generally a somewhat higher oxide content would be used replacing the sil-o-cel. It gave the softest of the floors, and in the cases of the use of the oxides burned at $800^{\circ}$ or lower, this characteristic approached that of mastic floorings. When this mix gave a harder floor as when the oxides from magnesite $\mathrm{A}$ (burned at $900^{\circ}$ ) and $\mathrm{D}$ (burned at $850^{\circ}$ ) were used, it cracked somewhat, though generally adhering well to the concrete. Mix $\mathrm{F}^{\top} \mathrm{T}-3$ gave a flooring intermediate in hardness between $F$ T $-I$ and $F$ T -2 . But one panel, made of oxide from magnesite $\mathrm{D}$ burned at $850^{\circ}$, 
cracked. It adhered well to the concrete. When the condition of the panels is studied from the viewpoint of source of the ore, there can be but little difference noted in the conditions of the several panels. Studied from the viewpoint of the temperatures of burning, no oxide burned below $900^{\circ}$ can be considered entirely satisfactory.

\section{CONCLUSIONS.}

I. In order to obtain a caustic magnesia of the optimum properties for use in making oxychloride stucco or flooring from ores of different origins, a study of burning conditions must be made for each ore. This should include a determination of both the temperatures and duration of burning of the uniformly sized ore. This is due to the fact that ores of different origin may, and generally do, require different conditions of burning.

2. Very light calcination produces a magnesia too active for present practice unless it is "aged" by exposure to moisture. Even then its use is dangerous, owing to the excessive contraction which often occurs under such conditions. In no instance was an ore calcined to a sufficiently high degree to produce undesirable effects.

3. The tendency to condemn an oxide because it will not produce a satisfactory product when used in a given formula is at fault. The same oxide can generally be made to produce a good result by changes in the formula.

4. On the other hand, a change in one or more of the aggregates in a formula may cause an oxide to give unsatisfactory products, though the same oxide has given satisfaction before the change.

5. The oxides have acted differently in flooring than in stucco formulas. The results lead to the conclusion that in order to produce the most satisfactory material, a different oxide is required for flooring than for stucco. In other words, an oxide which is highly satisfactory for the type of mixtures used in flooring will not give the greatest satisfaction in stucco or vice versa. This statement should be interpreted broadly, otherwise it would be contradictory to the second conclusion.

6. The magnesia has a great deal to do with the water resisting properties of a hardened composition, but the effect of the mix predominates. A number of magnesias tested in one mix probably would not fall into the same relative positions if tested in another.

7. The influence of the magnesia predominates over that of the mix in effecting the volume changes. All test bars containing 
the very lightly calcined magnesia contracted and those containing magnesia calcined at $900^{\circ} \mathrm{C}$. or above expanded.

\section{APPENDIX.}

In Tables I and 2 (printed below) are presented data obtained from testing, according to the methods outlined and followed in the main part of this investigation, two samples of oxide made by commercial producers of caustic oxide. The oxide $F$ was secured from a manufacturer using crystalline magnesite from a mine located but a few hundred yards from that producing the oxide $\mathrm{A}$ of the main part of this investigation. The kiln used for calcination was one especially designed for uniform calcination at the relatively low temperature used for producing caustic oxide. The sample represented some of the earlier output of the kiln. The calcination had been carried further than the analysis would indicate, as the high ignition loss does not indicate underburning as much as the effect of aging due to the long lapse of time while in transit to the bureau, and also to the small size of the shipment. This is further indicated by the slow set followed by a good hardening, these latter showing the effect of storage of certain oxides far more reliably than chemical analysis, which can not distinguish between low burning and storage effects.

The oxide $\mathrm{E}$ was calcined in a rotary kiln by the producer of California magnesite $\mathrm{C}$ used in the major portion of the investigation.

The results obtained by the use of these two oxides show a marked similarity to the data obtained with the ore from these same sources when calcined on a laboratory scale. The oxide from the crystalline magnesite as produced in the laboratory by calcination at $900^{\circ} \mathrm{C}$. gave uniformly better results than the oxide produced commercially. If allowances are made for the changes during shipment, the commercially calcined would possibly be on a parity with the laboratory-prepared product. The oxide made from the amorphous ore calcined at $\mathrm{I}, 100^{\circ} \mathrm{C}$. is, in general, much superior to the commercial oxide from the corresponding ore; that calcined at $900^{\circ} \mathrm{C}$. in the laboratory is inferior to the commercial oxide when used in a flooring mixture, but more nearly on an equality when used in a stucco mixture.

The study of the results of the data from these two oxides in connection with the other data presented herewith was to show how nearly the usual semipractical or miniature operating plants 
used by this bureau, and exhibited in the present case by the miniature Portland-cement plant, can approach in their operation the making of a product similar in most properties to that produced in full-scale plants.

TABLE 1.-Results of Tests of Two Commercial Oxides.

RESULTS OF CHEMICAL ANALYSIS.

\begin{tabular}{|c|c|c|c|c|c|c|c|c|}
\hline Oxide. & $\mathrm{SiO}_{2}$. & $\mathrm{Fe}_{2} \mathrm{O}_{3}$. & $\mathrm{Al}_{2} \mathrm{O}_{3}$ & $\mathrm{CaO}$ & Mgo. & $\mathrm{CO}_{2}$ & $\begin{array}{l}\text { Ignition } \\
\text { loss. }\end{array}$ & $\begin{array}{l}\text { Insoluble } \\
\text { residue. }\end{array}$ \\
\hline $\begin{array}{l}\mathrm{E} \ldots \ldots \ldots \ldots \ldots \\
\mathrm{F} \ldots \ldots \ldots \ldots \ldots \ldots\end{array}$ & $\begin{array}{l}8.16 \\
1.70\end{array}$ & $\begin{array}{l}0.53 \\
1.13\end{array}$ & $\begin{array}{l}2.26 \\
1.72\end{array}$ & $\begin{array}{l}3.60 \\
2.59\end{array}$ & $\begin{array}{l}81.72 \\
84.00\end{array}$ & $\begin{array}{l}0.95 \\
3.11\end{array}$ & $\begin{array}{l}3.94 \\
9.00\end{array}$ & $\begin{array}{l}9.89 \\
4.09\end{array}$ \\
\hline
\end{tabular}

RESULTS OF PHYSICAL TESTS.

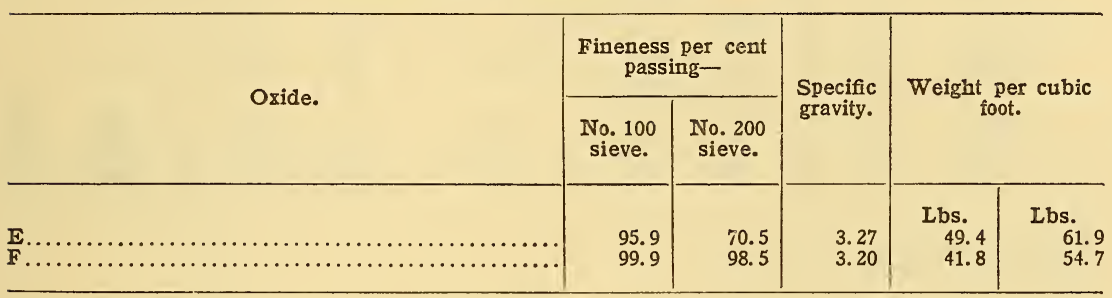

TIME OF SET.

\begin{tabular}{|c|c|c|c|c|c|}
\hline \multirow{2}{*}{ Oxide. } & \multirow{2}{*}{ Mix. } & \multicolumn{2}{|c|}{ Initial. } & \multicolumn{2}{|c|}{ Final. } \\
\hline & & Hours. & Minutes. & Hours. & Minutes. \\
\hline E...... & 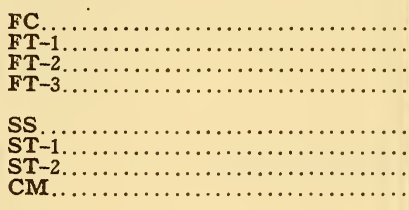 & $\begin{array}{l}4 \\
4 \\
5 \\
4 \\
5 \\
3 \\
3 \\
2\end{array}$ & $\begin{array}{l}15 \\
10 \\
20 \\
12 \\
05 \\
35 \\
30 \\
00\end{array}$ & $\begin{array}{ll} & 8 \\
& 6 \\
& 8 \\
(1) & \\
\text { (1) } & \\
6 \\
6 \\
4\end{array}$ & $\begin{array}{l}00 \\
05 \\
00 \\
\ldots \\
\cdots \\
35 \\
00 \\
30\end{array}$ \\
\hline F.... & 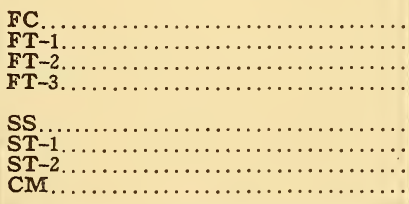 & (1) $\begin{array}{l}6 \\
6 \\
6 \\
6 \\
6 \\
5 \\
2\end{array}$ & $\begin{array}{l}30 \\
40 \\
25 \\
00 \\
45 \\
30 \\
55 \\
40\end{array}$ & $\begin{array}{r}24 \\
23 \\
25 \\
21 \\
48 \\
22 \\
22 \\
5\end{array}$ & $\begin{array}{l}00 \\
00 \\
00 \\
30 \\
00 \\
00 \\
00 \\
25\end{array}$ \\
\hline
\end{tabular}

\footnotetext{
${ }_{1}$ Set between 7 and 24 hours.
} 
TABLE 2.-Tensile and Transverse Strengths of Two Commercial Oxides.

\begin{tabular}{|c|c|c|c|c|c|c|c|c|c|c|c|c|c|}
\hline \multirow{4}{*}{ Oxide. } & \multirow{4}{*}{ Mix. } & \multicolumn{6}{|c|}{ Tensile strength. } & \multicolumn{6}{|c|}{ Transverse strength (modulus of rupture). } \\
\hline & & \multicolumn{6}{|c|}{ Storage. } & \multicolumn{6}{|c|}{ Storage. } \\
\hline & & \multicolumn{4}{|c|}{ Air. } & \multirow{2}{*}{$\frac{\text { H. }}{\begin{array}{c}28 \\
\text { days. }\end{array}}$} & \multirow{2}{*}{$\frac{D .}{\frac{28}{\text { days. }}}$} & \multicolumn{4}{|c|}{ Air. } & \multirow{2}{*}{$\frac{\text { H. }}{\begin{array}{c}28 \\
\text { days. }\end{array}}$} & \multirow{2}{*}{ 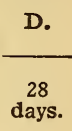 } \\
\hline & & 1 day. & 7 days. & $\begin{array}{c}28 \\
\text { days. }\end{array}$ & $\begin{array}{c}1 \\
\text { year. }\end{array}$ & & & 1 day. & 7 days. & $\begin{array}{c}28 \\
\text { days. }\end{array}$ & $\begin{array}{c}1 \\
\text { year. }\end{array}$ & & \\
\hline E.. & $\begin{array}{l}\text { FC... } \\
\text { FT-1. } \\
\text { FT-2. } \\
\text { FT-3. }\end{array}$ & $\begin{array}{l}300 \\
420 \\
365 \\
405\end{array}$ & $\begin{array}{l}330 \\
375 \\
330 \\
400\end{array}$ & $\begin{array}{l}415 \\
640 \\
435 \\
455\end{array}$ & $\begin{array}{l}430 \\
595 \\
510 \\
510\end{array}$ & & & $\begin{array}{r}615 \\
1,080 \\
805 \\
865\end{array}$ & $\begin{array}{l}745 \\
985 \\
770 \\
880\end{array}$ & $\begin{array}{r}865 \\
1,440 \\
955 \\
1,105\end{array}$ & $\begin{array}{l}1,190 \\
1,720 \\
1,280 \\
1,520\end{array}$ & & $\begin{array}{l}\cdots \ldots \ldots \\
\cdots \cdots \cdots \\
\cdots \cdots \cdots\end{array}$ \\
\hline & $\begin{array}{l}\text { SS.... } \\
\text { ST-1. } \\
\text { ST }-2 . . \\
\text { CM... }\end{array}$ & $\begin{array}{l}185 \\
235 \\
280 \\
240\end{array}$ & $\begin{array}{l}230 \\
230 \\
340 \\
275\end{array}$ & $\begin{array}{l}175 \\
360 \\
400 \\
395\end{array}$ & $\begin{array}{l}120 \\
260 \\
605 \\
605\end{array}$ & $\begin{array}{r}185 \\
170 \\
360 \\
2125\end{array}$ & $\begin{array}{r}205 \\
270 \\
415 \\
2195\end{array}$ & $\begin{array}{l}445 \\
510 \\
730 \\
575\end{array}$ & $\begin{array}{l}490 \\
545 \\
785 \\
790\end{array}$ & $\begin{array}{l}420 \\
500 \\
885 \\
940\end{array}$ & $\begin{array}{c}(1) \\
745 \\
1,410 \\
1,245\end{array}$ & $\begin{array}{l}390 \\
390 \\
415 \\
355\end{array}$ & $\begin{array}{l}450 \\
690 \\
920 \\
790\end{array}$ \\
\hline F.... & $\begin{array}{l}\text { FC... } \\
\text { FT- } 1 . . \\
\text { FT-2.. } \\
\text { FT-3.. }\end{array}$ & $\begin{array}{r}95 \\
155 \\
95 \\
165\end{array}$ & $\begin{array}{l}240 \\
320 \\
205 \\
220\end{array}$ & $\begin{array}{l}355 \\
505 \\
410 \\
425\end{array}$ & $\begin{array}{l}365 \\
610 \\
385 \\
505\end{array}$ & & & $\begin{array}{l}(1) \\
370 \\
(1) \\
285\end{array}$ & $\begin{array}{l}470 \\
800 \\
430 \\
600\end{array}$ & $\begin{array}{l}725 \\
995 \\
720 \\
865\end{array}$ & $\begin{array}{l}1,075 \\
1,630 \\
1,115 \\
1,505\end{array}$ & & $\begin{array}{l}\cdots \\
\cdots \cdots \\
\cdots \cdots\end{array}$ \\
\hline & $\begin{array}{l}\text { SS ... } \\
\text { ST-1.. } \\
\text { ST-2.. } \\
\text { CM... }\end{array}$ & $\begin{array}{r}60 \\
70 \\
105 \\
195\end{array}$ & $\begin{array}{l}125 \\
160 \\
250 \\
340\end{array}$ & $\begin{array}{l}120 \\
180 \\
385 \\
460\end{array}$ & $\begin{array}{r}75 \\
245 \\
565 \\
455\end{array}$ & $\begin{array}{l}105 \\
175 \\
300 \\
300\end{array}$ & $\begin{array}{l}135 \\
240 \\
345 \\
385\end{array}$ & $\begin{array}{l}(1) \\
(1) \\
(1) \\
270\end{array}$ & $\begin{array}{l}(1) \\
395 \\
560 \\
605\end{array}$ & $\begin{array}{r}375 \\
545 \\
895 \\
1,040\end{array}$ & $\begin{array}{c}(1) \\
900 \\
1,560 \\
1,205\end{array}$ & $\begin{array}{r}315 \\
485 \\
730 \\
2680\end{array}$ & $\begin{array}{r}390 \\
770 \\
865 \\
21,415\end{array}$ \\
\hline
\end{tabular}

1 Modulus of rupture less than $200 \mathrm{lbs}$./in. ${ }^{2}$

${ }^{2}$ Specimens cracked.

WASHINGTON, April 20, I923. 